\title{
English Studies and Future Career Opportunities: How English Students Construct Themselves in a Ghanaian University Department
}

\author{
CASIMIR ADJOE, Phd \\ Institutional Affiliation: Central Universitypostal Address: Central University, P.O. Box 2305, Tema, Ghana
}

\begin{abstract}
The paper examines how English students in an English department construct their identities in relation to their discipline and its opportunities for job entries and career development in comparison with the study of other disciplines. Using a combination of questionnaires and interviews, it solicited responses from students in an English department which it analyzed and concludes that students identify themselves closely with English because of its perceived qualities of enabling them to think critically and creatively thereby making them able to communicate effectively; it consequently serves as a foundational course opening up all job and career avenues to them. In short, it develops their consciousness and starts them at advantage in career development in comparison with students of other disciplines.
\end{abstract}

Key Words: Consciousness, Critical or Powerful users of language, Expectations, Life chances or future opportunities, Study of English, Textual Power.

\section{INTRODUCTION:}

This paper began as a private study of the needs of students of English for the construction of course outlines for teaching in a Ghanaian university department. The study, however, began to turn out unexpected and interesting issues about what seemed to be indications of a shift in student thinking about the study of English. The aim of the study, although remaining in the purview of the needs of students of English, nonetheless, shifted focus to the problem of relating the study of languages, and specifically, English, and its perceived prospects to job opportunities and career development in the university curriculum. The interest in this problem is due to the shift in perception of students from anxiety and lack of interest in language studies to confidence about language and its opportunities for consciousness and career development, and hence the manner in which language and communication affect learning interests and outcomes in the context of African university departments. The orientation of the research is hence to explore and to gain insight into how English students construct their identity as English students in relation to their future career options. In effect, it could clarify some of the constructs or motifs upon which students are attracted to English courses in our contemporary African context. Besides, the study may afford the opportunity to understand what kinds of identity English students expect or want to create for themselves when they select a course in English, and what these are based upon for their own marketability and the improvement of their life chances. Reading an MA thesis in Management Studies in which a student was constructing the identity of management students and where they fit in the job market put a perspective on the expectations of students and what they were attempting to articulate. I began to ask myself how students of English conceive of themselves and how they in turn construct their identities in spite of what already exists institutionally as fixed knowledge. In the view of the MA thesis in Management Studies, Management students' identity is embedded in how much they are sought after as professionals to perform specific roles in society.

It is apparent that students of Management Studies, and of other Business courses, can describe precisely how they fit into any workplace or organisation, or how, when and where they can so fit. Thus, they have both a head start and a starting point in job prospecting situations as they are able to define themselves and their identity, and consequently, what they can do and what they cannot do, and also able to evaluate what they stand for in relation to others in their organisations, their needs, their ethos, their progress or otherwise, and be able to determine what kinds of improvement they need and how to achieve them. Thus, when they apply for jobs, they can already figure out where they can fit, what would be expected of them, and what they need to do to be able to satisfy the expectations of the jobs they seek. In this way, students doing business courses are more likely to know what jobs they can apply for, and can adequately prepare for job interviews. How do English students, on the other hand, perceive and represent themselves? Are they able to do so, and what are the significant elements and the 'grammar' they employ to do so, if they do at all? And what will the outcome of such a project be? 


\section{FRAMING THE BACKGROUND: STUDENTS AT A LOSS:}

In a recent radio preaching at a local FM radio station, a preacher talked about the study of English. He argued that he knew how to speak English, so do many others who are in school, and it is heard spoken everywhere; yet so many people still learn English in universities and the subject is still considered important. He was at a loss to understand what people who continue studying English to such levels in the university still do in terms of acquisition of knowledge and its usefulness, and wondered what exactly the contents and their worth are for its individual patrons and for society.

In part, that echoes a general feeling ranging from employers to parents, and more often than not, even to students in the English department themselves. It accords with fears expressed by students themselves and their parents and other interactants who asked many questions of English graduates, leaving them in near despair in earlier exploratory interviews and studies I carried out from 2010. Students themselves began to ask very serious questions about what they would do with English apart from teaching in the Primary and Secondary schools after their studies. For that reason, their anxieties generated a strong craving for combination of courses

English with Business courses in particular - because they did not foresee any worthwhile employment opportunities with a qualification in English, or exactly what such a degree could be used for, on account of the many questions posed by their interactants, which they were unable to answer. Their fears were reinforced by the fact that employers, for instance, do not advertise specifically for English graduates.

In all this, however, the student of English will have to apply for a job. The question then is, how does he or she define, justify, and project his or her qualification and the course they read to enable it fit into the world of work, or to be significant for any context in which he or she might want to be included? This exploratory study is therefore designed as a study of what students themselves understand about themselves as English students, and what they perceive their identity to be or what they want it to be perceived to be according to their experience of the discipline, and what this identity represents for their life chances and job opportunities, and what it represents for them in relation to colleagues who offer other courses.

For this reason, this exploratory study has used as its population for study, students from the second year of the Bachelor of Arts English Studies to the fourth year of studies in a University in Ghana. These students, who already have had at least a year's acquaintance with the courses in English and have experienced its contents and directions may be presumed to have settled for themselves what English offers them in respect of life chances and job opportunities and hence be better able to speak to its value for them. Consequently, it is expected that they would be able to define what these values are, and what constructs they employ to describe these values, and eventually, how these definitions will delineate the identities they are constructing for themselves as English students.

\section{METHODS OF RESEARCH:}

In this exploration, in-depth interviews were conducted for five students in Level 200 and Level 300. Two students were randomly selected from Level 200 from among seven students in the class, and three students were also randomly selected from Level 300 from among 23 students. The five students volunteered after an initial thirty questionnaires were circulated among students in each class of the four levels. The questionnaires were designed to include mainly open-ended questions. Twenty-seven questionnaires were returned. The questionnaires that were returned gave the clues as to what kind of questions and focus would enable in-depth interviews with the volunteer interviewees.

\section{TEN MAIN ITEMS FOR INTERVIEWS:}

The main items on which the questionnaire focused were: What motivated students to choose English as a course; what their expectations were about the course and how those expectations were met or not met; how they understood English as a course; what aspects of the course they liked best and why; what kind of life chances they thought the course offered them; and how they perceive themselves in comparison with their counterparts offering courses such as Business and the Social Sciences that seem to offer straightforward job opportunities and life chances.

\subsection{Motivation:}

What motivates students to choose English as a course is varied. But a number of key things can be identified: a) The attraction of the English language itself: As a student put it, 'I love the language'. When pressed further to explain why she loves the English language, she explained that it is because she wants to be one of the most prominent women in the world, and she believes that studying English can give her the edge over her competitors. It will be, as she expressed it, 'one of the weapons against my competitors'. The manner in which English would become a 'weapon' for her against her competitors is through studying Law, and gaining the ability to write books and news. For this student then, English is an instrument of pure competition, a means by 
which to win in the struggle for life chances and job opportunities, as well as for establishing a distinctive identity among other women of prominence by means of quality knowledge and use of language.

b) Another student who was motivated by the interest in the language was so motivated because he wanted to speak the correct English as compared to others, also emphasising the motif of competition, but in relation to excelling in communication in conformity to institutional norms.

c) However, another student, although also motivated by the desire to have a command of the language and the ability to communicate, emphasised the aspect of 'exposure' to knowledge and the world that the English language enables for those who have a command of it in communication. In this view, the ability to communicate ushers the beneficiary into a world beyond her own in both interaction with others, and in the access to resources in books and other sources that employ English.

d) A fourth interviewee was also concerned about 'exposure', in the sense that the study of English widens and broadens knowledge. She was interested in harnessing this sense of widening and broadening knowledge through English in preparation for reading Law. Thus, in this context, English becomes a foundation for framing other courses and future prospects of success in the chosen areas of interest, in this case, Law.

e) A fifth student, however, felt compelled to read English as a course because she had no option. It happened because, in her own words, 'I actually chose to offer Human Resource Development, but had no option than to choose English since I was not offered the HRM course'. The English course, for this student, became a self-imposed obligation. This obligation, however, also imposed upon her great adjustments and created challenges for her studies which she was overcoming; nonetheless, she was not embittered by her encounter of English as a self-imposed obligation, but was rather gratified that although challenging, she was getting a grounding in the course as she would not have imagined beforehand. The fact that this student does not feel embittered about her self-imposed obligation of choosing English in spite of the difficult adjustments it calls for, point to the value she thinks she has found the study of English to be for her. She has come to the conclusion that through the study of English, she can develop values and skills as close as possible to those that Human Resource Management may have offered her.

\subsection{Expectations of English courses and whether they have been met:}

Once students have been motivated in one way or the other to study English for a degree, it is important to know whether the various expectations they had of their course in English has been met or is being met, and which of them have been met, and which others are still yet to be met. Thus, concerning their expectations, all the interviewees acknowledged a fulfilment of their expectations. In this respect, a student admitted that, 'Well, offering English as my option has been really challenging.' This student had imposed upon herself the obligation of choosing English as her only remaining option because she was not offered her preferred course in Human Resource Management. She found the English course challenging; but she did not regret choosing it as a course in view of lack of future prospects in using the knowledge gained from it. Her difficulties were due to the adjustments she had to make psychologically and, the efforts she had to make to sustain interest in the course, because of the amount of resources she needed to mobilise to meet the expectations of the course lecturers.

Another student conceived of meeting her expectations of the course through how well she was performing in her examinations; thus: 'By God's grace I am still trying my best; so far, I have been doing well in all my papers and courses'. One student understood this in terms of having a command of the English Language in that he is confident that he is now able to speak English much better than before, and hence has seen much improvement over what he used to be. Yet another student conceived this in terms of the 'correct pronunciation of words, and a better understanding of people in conversations'. She, thus, signals that her expectations for learning English are being met in her ability to communicate better, and in understanding other participants in the communication process better, hence being able to appreciate the process and context of communication through a greater knowledge and command of the English language. A fifth student believes that mastering the English language has enabled him to achieve two things that he did not notice before: i) she could now write short stories, and ii) whenever she communicated, people were able to recognise a unique difference between her communication and that of others who are, presumably, not English students.

In those cases where students still felt some need to fulfil their expectations, it related to 'understanding of a text resulting in the ability to analyse it properly'. Students are thereby relating understanding of text to the ability for analysis of text, pointing to the need for an emphasis on the acquisition of clear and specific instruments of analysis that could enable them to penetrate texts. This is also expressed by a student who expressed doubt about her own ability to understand text in the way that she actually desires, pointing to her lack of a concrete technique, and stating that "Probably I am lacking in some technique in reading and understanding text.' One student felt that he cannot assess the fulfilment of his expectations in total yet; as he reckons, he can only do so by the end result when he begins to read Law as his second degree, or when he begins to practice as a journalist; and yet another thought that since she regards English as a basis for all the other courses, she expects that her mastering of English would manifest in her performance in the other courses 
she was taking by scoring A's only. In this case, English is conceived of as a foundational course that enables better performance in all other areas of academic work and undertakings. Consequently, its total value can only be assessed in the long term, and not in the short term.

\subsection{The understanding of English as a course of study:}

The understanding of English as a course of study is pertinent as students regard it as a foundational course for understanding all other courses and for boosting performance in these courses as well as in preparing for postgraduate work. To this question, a student replied that: 'I did not understand the course at first, but I am getting to understand it now.' But how is she understanding it now? She understands it as 'a course that enlightens one to think critically and to be very analytical in dealing with issues. It makes one to be very outstanding.' Other students explained that 'English as a course is more than the studies of the language. As I move ahead in the studies, I am exposed to all aspects of working knowledge, and I am really glad for this. The myth that most English students become teachers is no more a stigma.' In understanding English then, students emphasise the critical and analytical skills they acquire through it, or which they expect to acquire through its study, the exposure to 'more than the studies in language', and the dispelling of the myth that students who learn English's occupational value is limited to teaching in the classroom, which is also a coded reference to low level employment and low level remunerations.

\subsection{Where students get their understanding of English from:}

It is important to establish where this kind of knowledge and confidence comes from so that students are not left in any aberrations. Students are certain about where they are constructing their views and perspectives of English. Perhaps the most convincing is from their own participation in the English courses they offer, and since most of them also offer other courses in Business as combined minor courses, they are able to assert their perspectives from a point of comparison with the courses outside English which they participate in. Hence they are able to respond that their perspectives have been gathered from the 'Various courses offered during my studies'. Other sources from which they construct their perspectives derive from the media: from foreign news, especially the BBC, from Joy FM, and others. Some other sources apart from the media include attending symposia, seminars, reading books, articles, news and entertainment, and above all, from observing people who have read English to the highest level in the society.

\subsection{What aspects of English do students like most?}

At least three out of the five students interviewed preferred grammar and its related aspects to Literature. Only one student liked both grammar and literature and language studies together. Two other students liked Literature and script writing. Those who liked literature and script writing do so because 'they help me to express myself', and through script writing 'I get to develop a special skill'. And for those who prefer the grammar and its related aspects, they do so, 'Because I would not like to make mistakes when speaking. Also, to be able to help others who have problems with grammar'; and also because 'It improves the quality of words and pronunciation through phonetics and phonology'; and because apart from the lecturers' ability to explain well, they are also able to broaden the student's mind about the classification of grammatical structure. Whereas, for the student who liked both grammar and literature, and language studies, all the aspects of English studies involve reading, yet they help one 'to move beyond just reading to analysing what I read as well'.Thus, being able 'to express myself', and developing a special skill for writing and for the analysis of what is read seem to be crucial factors in determining students' orientation to the aspects of English studies they prefer, as much as in selecting English as a course for study. And so how do these assist their life chances or opportunities in life?

\subsection{English and the chances of success in life:}

Students are deeply concerned about their chances of success in life, and the courses they offer are of value in opening up those prospects of success for them. It is a crucial element in the choice of courses as students make comparisons across courses and assess their chances for employment and the maximisation of their future opportunities for a life worth living. Consequently, it is beneficial to understand how students understand where they fit into the world's economy and its scope of offering job opportunities and the distribution of success. In this regard, students were quite certain they have sufficient answers in studying English to be able to make life a success just as much or better than others across the various courses. They reckon, for example, that 'because English makes my understanding of things easier - also, it is making me a critical thinker; I think I would be able to work in any company with respect to communication'. Others reckon that 'Studying English widens one's scope academically and therefore enables one to operate in any field of endeavour as one is not limited to a particular field only.' Another student thinks that 'In journalism, my chances are high and are going to bring success.' A student is certain that he can enter the business world and 
make a success of it because, 'English is one of the prominent languages in the world. In business, it is believed that communication is currency so I believe that English is my currency for success in any and all business ventures.' And yet another student believes that her chances of success with English are very high, 'because one is more like a communicator and mostly these days companies like to recruit one who can communicate well on behalf of them - such as in journalism, reporters, translators, public relations, etc.'In this regard, compared to students offering courses in other areas like Business, Applied Sciences, Economics, etc, the English student sees herself or himself in relation to their chances of success in life as favourably comparable, if not better. In this respect, those who compare their chances of success in relation to the combined courses they are offering are able to reckon that: 'Well, I think English makes an individual unique and for someone like me offering English with Human Resource Management, I am more versatile than others offering just Business or Science courses'. In another regard, one student observed that 'It is very easy to panic and compare yourself as inferior to the other students when we meet, but I no longer see that as a problem. Whenever we interact, either in studies or just in communication, the English students are distinct in their delivery and even sometimes others ask us about our understanding of a topic or course and then pick their points from us.' Another student thinks that 'I see all to have the chances of success depending on the type of person one is. However, we are needed everywhere, so I think we have higher chances of being recruited by companies.' In the view of another, 'English courses take you far and can give you different chances in your success or in your life process.' However, one student seems to summarise it all in saying that 'The study of English automatically accords one some level of respect in society, firstly, with the notion that it is a difficult course; secondly, being analytical and critical, the English student is able to bring about a different approach to handling difficult issues compared to others.'

In conceiving of English and the chances it offers for their chances of employment, future opportunities and chances of success in life, students point mainly to the critical and analytical skills acquired through the English studies which enables the quality of bringing about different approaches to handling difficult issues compared to others, to its value as a 'currency' for every aspect of life, including business, to the field of communication, to the possibilities offered to be creative and versatile, to the distinctiveness in the ability at delivery or presentations due to communicative competence, and to the fact that studying English widens one's scope academically and therefore enables one to operate in any field of endeavour as one is not limited to a particular field only. As a result, as students perceive it, studying English is an advantage both academically and professionally, offering chances for building success for their lives in future; hence English is a course that is not risky for job opportunities, but rather an insurance for job opportunities as it can be regarded as 'currency' in the field of professional development.

\section{THE IMPLICATIONS OF STUDENTS' DEFINITION OF THEMSELVES THROUGH ENGLISH:}

The positive views expressed in the interviews by students about English have not always been so, as an initial exploration about the study of English in 2010 portrayed a completely different picture of English. And so what has changed in students' perceptions of the course and why?

In 2010 the questions asked by students, and quite often, not by people outside the English departments, but by people who found themselves in the department who then began to question themselves as to whether they had made the right choice or had been mistaken in their choice, corresponded with those asked by many other people. Quite often, students' anxieties were raised by the sympathetic sighs and anxieties of others about what they were going to use English or language for in an age where money-making, enterprise and hard knowledge in technology, science, business practices and other tangible fields of study are the normal way to go. English studies or language studies in general thus assumed a perspective of an anomaly, and students and practitioners of English and language began to be tempted to feel and look like anomalous beings. The same questions asked by students who were reflecting upon their being in the English or language department were asked by many educated people - by parents, by employers, and by many other varieties of people. Such questions ran as follows: 'Why English Language?' 'What do you want to use it for?' 'But English is no longer fashionable these days?' 'Do you want to be a teacher?" 'What shall I use English for - I can only be a teacher?' became the main questions posed by students to their tutors as it appeared that English studies were not a very strong guarantee for employment. In the view of students and parents, few, if any job adverts asked for English graduates, at least as patently as for other courses or subjects in the fields of Business, Science and Technology. The closest to such advertisement is that a job applicant must have had a credit pass in English Language, or have good communication skills.

It became apparent that English students, fearing for their own futures, and not being too sure of the value of their final certificates for the modern market, were showing their anxieties in the questions they were asking, and now translating them into the agitation for combining English with other subjects. An inquiry from two final year students who had been combining Human Resource Management during the academic year, why 
they chose the combination and did not focus on English, although asked on different occasions, cited the job market in their replies. Both answers were nearly identical in stating that holding an English certificate alone did not guarantee a job.

Each year, from observations in 2010, quite a few students sought either to quit the English course or sought the means to combine their English courses with other courses outside the English department. Those who had applied for other courses and were yet unable to get placement into them and who were given alternative courses in the English department sought by all means to wrestle out of the scourge of English, and those who remained were always seeking a combination of English with some other Business or Management Course. In 2010, a whole class of students in the second year was anxiously seeking to know whether they would be permitted to combine courses. When they were asked to know exactly what they were suggesting, they explained that they would prefer to have another course in a Business department as a minor subject in combination with their English major.

Incidentally, what the students were asking for can be understood from a position advocated by Scholes (1998), in response to similar problems and anxieties he had noticed in English departments and among English students in the Unites States and in Europe in the three decades preceding the 1990s. Albeit, he was careful in endorsing the trend with the caution to avoid the danger of just combining courses in what he refers to as a 'shopping mall' fashion, that is, in a fashion lacking focus or systematic structure and thereby posing the danger that students finish the course of study without a disciplined knowledge of any field of study in particular. To forestall such a situation, although he clearly perceived the advantages of a well-planned combination of courses, he advocated that "'As members of a discipline, an English faculty should be able to insist that students take a configuration of courses in other disciplines that will allow them to attain the competence and confidence that they seldom achieve at present.' (Scholes 1998:157),

It thus seems that by 2010, the English curriculum in the university being used as a case study was generating anxieties among students, given their response to the relevance of the course to them in seeking jobs and for their chances of success in life. The response of students in 2013, being a complete reversal of the anxieties of 2010, also indicates a change of ethos and orientation in English studies in the university. This paper argues that in today's world where the thrust for most people is to find new positions and new ways of seeing the world, and new ways of describing the old, and of making new meanings out of the old, and where meaning making is far more emphasized over ready-made 'truths', approaches to teaching English that exclude these assumptions are more likely to create anxieties in students as they may not be able to have a compass to where the course is directing them, thus consigning English to irrelevance. Birch (1989), in speaking to this kind of issue, and therefore about the possibility of making English courses relevant, identified two types of relevance - one which he identifies as an insistence on the intrinsic or contextless interpretation of English studies, which in fact has led to the consignment of the study of language into irrelevance, and the other, extending more into context, enabling the instruments and resources for grappling with immediate problems and issues by involving itself in the world, and thereby relational to both worldly interests and individual interests (pragmatic). This latter approach enables the relationship of English study to be established with relevance rather than studying English simply for its own sake. Birch (1989), thus, seems to suggest that this latter approach can enable English departments to reawaken themselves into relevance and significance by turning into a more critical theoretical direction. The critical theoretical direction is promising in being able to provide the instruments and resources for fashioning products equipped with a critical consciousness and education, and with questioning minds, and hence tending towards a creative and problem-solving direction. Such a direction has made language courses educational as they are designed to develop critical and analytical skills leading to creativity or innovation and versatility, not confined to any particular field, but panoramic enough to enable the English student to fit into any role or field with the potential of developing specific skills wherever the opportunities present themselves. Such a direction seems to have also been given concrete design in a number of directions, but above all in the Language as social practice outlook, some of which aspects, operationalised under the critical discourse analysis tradition, are described by Wallace (2003) as helping to 'develop the language in cognitively and critically challenging ways' (Wallace 2003:5). Wallace (2003) understands the acquisition of such expertise as the consequence of an integrated approach to the teaching of language and a holistic acquisition of language abilities through the emphasis on becoming better readers of text. Better reading of texts necessarily enhances overall knowledge and use. And in laying emphasis on the adjective, 'better', she points out how it must be understood: ' When I say 'better', I mean more critical, more powerful users of a language, in this case of a second language." (Wallace 2003:4). Wallace's views corroborate those of Scholes (1998), explaining more urgently why we need to prepare students as critical and hence powerful users of language. It is inevitable, given the course of globalization and post-modernism, that as Scholes (1998) observed, now more than ever, the graduates of our schools and colleges will live in a world different from those in which they were born and went to school. The discipline called English, and Language should therefore tend towards helping the majority of people to prepare for unknown conditions. Following Scholes (1998:158), 'The 
best preparation we can give our students hence will be the highest level of competence as readers and writers, producers and consumers of the various texts they will encounter. In the end, it should be possible to enable the creation of the kind of graduate students who embody at the same time, the "tolerant, skeptical and interested".

As a way of considering developing the kind of project Wallace (2003) and Scholes (1998) suggest, it is possible to, in a preliminary manner, to examine language as Donaldson (1987) does in pointing out that even at a more abstract and generalised context, the pursuit of language is to work at the level of developing consciousness. Consequently, when the intellectually sophisticated adult employs language, they do so with the consciousness of language first as a formal system in terms of which one can construct the world. However, such a person also realises that meaning can be considered apart from any particular context of use, that is, meaning which is not totally embedded in events or in the ongoing flow of 'real life' and can be classified as a de-contextualised meaning. This kind of meaning may be referred to as idealised meaning. It is such decontextualised meaning that makes it possible to construct isolated sentences that can be applied to a variety of contexts in both time and space and makes it possible also to ask: 'What does it mean?' The implication of this kind of thinking is to describe the necessity of the development of a consciousness in the student that is capable and flexible enough to conceptualise, reconceptualise and re-contextualise meaning and knowledge. Consequently, de-contextualised knowledge serves only as a location for learning how to frame, position and integrate consciousness in readiness for the interpretation of new situations and problems in new spaces, times, and contexts, in creating new consciousnesses.

The emphasis on the development of consciousness in the learning of language and its related activities is the key here, and implies first and foremost, that it entails the development of self-consciousness or identity, the recognition and definition of consciousness itself and its application to understand individual items, isolated events and processes outside contexts, as well as in combination with their contexts. This understanding of language in relation to the development of consciousness suggests that in learning English, the fact cannot be overlooked that an emphasis on the development of critical thinking skills, critical analysis skills, innovation, leadership skills, and communicative skills (rhetoric) as a way of developing transformational and productive skills can serve English departments in Africa well in preparing students towards penetrating the future and the unknown in whatever space or time they may be re-contextualized or relocated.Consequently, the study of language opens the possibility for creativity and innovation in all areas of knowledge through carrying it forward via re-examining and redefining the idioms and metaphors on which life, activities, conceptualisations and discourses are based and operate for any moment. Thus, if people who do not know what students still study even in higher education as far as to university in language, or how language studies can still be relevant for employment and existence in the modern world and therefore wonder and question, it is because they generally think that language studies consist of simply imbibing a particular set of fixed rules that make a person competent in speaking a language and using it to communicate fluently. The thinking suspects a kind of mechanical acquisition of skills that can be set onto a production line of fluent communication without any relation to the development of consciousness. Such thinking can only be encouraged by the experience of how language is conceptualised and studied in the educational system of our schools. The challenge would be how to reconceptualise and reinterpret those fixed conceptualisations and reconstitute them towards the building of approaches to language learning and teaching that focus on the development of consciousness and critical analytical orientations conducive to preparing students for their lived world, as well as for new and changing conditions and contexts; that is, preparing them towards the ability to recontextualise knowledge and consciousness.

\section{CONCLUSION:}

From the students' responses in this study, it is apparent that they feel that the development of consciousness is the crucial element for their own development as well as for the resources and skills they need to acquire to be able to cope with the search for their roles in society and for their career prospects. It is also apparent that the effects of adopting an approach to the study of English or language with an emphasis on critical theories as core, supported by the insights of the historical, and insights into the effects of knowledge production and consumption, promote the development of critical and analytical skills through the way they question our way of structuring and categorizing reality, and thereby prompts us to break free of the habitual modes of perception and categorization that we have been used to (Barry 2001). These ways of teaching language meet the needs of students and empower them with the confidence they also need to practice these skills and take custody of the resources that the development of consciousness provides. As language is not simply representation or passing on information, it needs to be shown to be about action and interaction, performance, showing and about doing (Birch 1989). Understanding the nature of language in this mode also enables the understanding of people and the discursive practices they are engaged in. As Culler (1988) also argues with respect to English studies in the form of literary criticism, theory and the development of consciousness, a critical theoretical approach towards the study of language develops skills towards diversity, interdisciplinarity and multidisciplinarity, thus, enabling the panoramic application of skills and unlimited 
possibilities in the application of knowledge. The development of such consciousness also enables the development of the skills towards paying attention to new sorts of objects, new kinds of texts, and new kinds of ways of seeing the world. What these capabilities develop in the English graduate is the ability to venture into interdisciplinary encounters with growing confidence and sophistication, especially through paying attention to the mechanisms of signification which can be studied in a wide range of texts and text-like situations.English Studies, then, when sought as a discipline in the university in Africa today, is pursued primarily as a product for consumption for the attainment of jobs. However, students from my study do not want to see themselves as only consumers, but also producers of language that could aid and involve them in the most beneficial ways possible in the buying and selling in the contemporary world, and in their preparation for the unknown. Thus, students want to learn both how to be, and how to do - being and doing. Consequently, the task of English Studies, according to the students in this study, should orient more towards developing their consciousness and fashioning instruments of investigation to sharpen their critical abilities in order to give them what I shall describe in Scholes' (1989) words as 'Textual Power'.

\section{REFERENCES}

[1] Scholes, Robert, The Rise and Fall of English (New Haven: Yale University Press, 1998) (12)

[2] Birch, David, Language, Literature and Critical Practice, (London: Routledge, 1989) (12)

[3] Wallace, Catherine, Critical Reading in Language Education (Houndmills: Palgrave Macmillan, 2003) (13)

[4] Donaldson, Margaret, Children's Minds. (London: Fontana Books, 1987) (13)

[5] Culler, Jonathan, Framing the Sign (Oxford: Basil Blackwell, 1988) (15)

[6] Barry, Peter, Beginning Theory (Manchester: Manchester University Press, 1995) 